\title{
Chemotaxis Induction
}

National Cancer Institute

\section{Source}

National Cancer Institute. Chemotaxis Induction. NCI Thesaurus. Code C40751.

Chemotaxis Induction involves initiation of characteristic movement or orientation of an organism or cell along a chemical concentration gradient either toward or away from a chemical stimulus. 